\title{
Organic Farming Suffices to Feed a Country: a Large-Scale Linear Programming Model to Develop an Organic Agriculture Plan for Turkey
}

\author{
Bulut Aslan ${ }^{1} \&$ A. Yonca Demir ${ }^{2}$ \\ ${ }^{1}$ Business Analyst, Icron Teknoloji Bilişim, İTÜ Ayazağa Kampüsü, Maslak, Istanbul, Turkey \\ ${ }^{2}$ Business Administration Department, Istanbul Bilgi University, Eyüp, Istanbul, Turkey \\ Correspondence: A. Yonca Demir, Business Administration Department, Istanbul Bilgi University, Eyüp 34060, \\ Istanbul, Turkey. Tel: +90-212-311-7782. E-mail: ydemir@ bilgi.edu.tr \& ydemir968@ gmail.com
}

\author{
Received: November 1, 2017 Accepted: November 24, 2017 Online Published: January 5, 2018 \\ doi:10.5539/sar.v7n1p118 \\ URL: https://doi.org/10.5539/sar.v7n1p118
}

\begin{abstract}
A frequently voiced critique is that due to lower yields on organically managed farmlands, one cannot feed a country using organic agriculture. In this paper, we aim to mathematically disprove this claim by developing a linear programming model and produce a detailed agriculture plan for Turkey sufficient to feed her population with a $2400 \mathrm{kcal}$ daily menu on average, solely comprising of organic foods. The model uses information about population sizes and food needs of 81 cities in Turkey, and yields of 120 food, feed, forage crops, and four animal products. Intensive and extensive livestock production methods as well as food transportation between cities has been incorporated into the model. The resulting problem with 950 thousand variables and 40 thousand constraints can be solved with an optimization package in under a minute. Results, prescribing how many acres of each crop should be grown in each city, indicate that to feed the country fully on organic produce, $63 \%$ of the arable land suffices, yielding 8.9 million hectares of unused land where further organic foods could be grown for export or aid. We also run the model under different scenarios: fully vegetarian diet, omnivore model, different transportation structures, drought conditions and a limit on fruit trees. With this work, we have shown that it is possible to feed the whole population of Turkey with an agricultural practice that is not harmful to human health, soil, water and air; respects biological cycles and reduces food miles and fossil fuel consumption, thus contributing to sustainability and fighting climate change. We tested preliminary scenarios to understand the robustness of organic agriculture in the face of extreme weather events. The proposed model can also be applied to other countries when appropriate data are used.
\end{abstract}

Keywords: organic agriculture, linear programming, agricultural planning, farming, sustainability, arable land, fossil fuels, carbon emission, food miles, climate change, biodiversity, nutrition, goal programming

\section{Introduction}

A major effort goes into agricultural activities to produce food for the human population. For a long time, food production and distribution systems have been solely judged by one criterion: the economic value of food production and consumption. This fact encouraged the use of agricultural methods that make it possible to produce large quantities of food at the expense of degrading nature and society. The monoculture structure of these large-scale production systems is at the root of many economic problems for farmers throughout the world (Altieri \& Rosset, 1996). The situation is not different in Turkey; Keyder and Yenal (2011) report that deregulation efforts left small farmers vulnerable to the fluctuations of world markets on inputs and outputs. This, coupled with the commodification of land and labor, led small farmers to seek employment outside farming. Besides these adverse economic consequences for farmers, conventional agriculture is known to have several harmful effects on the environment and public health. Decreased biodiversity, contamination of water, soil and air are only a few of the problems generated, (Fukuoka, 1978; Rembiałkowska, 2007; Stolze, Piorr, Häring, \& Dabbert, 2007). Horrigan, Lawrence, and Walker (2002) list the human health effects of industrial agriculture as extensive use of antibiotics compromising their effective use in medicine, increased cardiovascular diseases and certain cancers from excessive consumption of animal fat, heavy use of pesticides increasing cancer risks for agricultural workers and consumers, and certain agricultural chemicals causing hormonal and reproductive 
problems. Taking an alternative position on food production, Cockshott and Cottrell (1993) argue that a better way to feed a population is by ensuring the sufficient intake of nutrients while showing care to the ecology. Using examples from Japan, Fukuoka (1978) proposes the use of small-scale organic farming to reverse the adverse effects of modern lifestyles on the ecology. A recent meta-analysis (Barański et al., 2014) reports that organic crops are indeed healthier with higher concentrations of antioxidants, lower concentrations of cadmium and a lower incidence of pesticide residues than their non-organic counterparts across regions and production seasons.

Based on principles of health, ecology, fairness and care (International Federation of Organic Agriculture Movements [IFOAM], 2008), organic farming is an answer to various other contemporary problems (Note 1). Organic farms' use of input energy is lower than conventional (Gündoğmuş, 2006; Delate, Cambardella, Chase, \& Turnbull, 2015) and the mean labor requirement per area is more on organic farms, about twice the conventional farm value (Morison, Hine, \& Pretty, 2005). Long-term organic comparison trials in the US have shown that organic practices have the potential to better store carbon and nitrogen, resulting in higher soil quality, and allowing farmers to remain competitive in the marketplace (Delate et al., 2015). These characteristics of organic agriculture provide a solution for the economic problems of farmers by reducing unemployment and the dependence on off-farm inputs and help farmers to capture a higher proportion of the value added by giving a specific position to their products (Keyder \& Yenal, 2011; Aktar \& Ananias, 2005).

Organic crops also perform better than their conventional counterparts during extreme weather events such as droughts and floods whose frequency has increased as a consequence of climate change, (Intergovernmental Panel on Climate Change [IPCC], 2013; Jentsch \& Beierkuhnlein, 2008; Rosenzweig, Iglesius, Yang, Epstein, \& Chivian, 2001). With higher levels of $\mathrm{C}$ and $\mathrm{N}$, greater resistance to erosion and an increased ability to capture water during heavy rain and to retain water afterwards, organic farms need less irrigation and report decreased levels of plant stress during drought (Liebig \& Doran, 1999). Lotter, Seidel, and Liebhardt (2003) found that water harvest, important for groundwater recharge, was significantly better in organic systems and argue that the better water holding capacity of organically managed soils is a likely reason for the better yields obtained during times of drought. Significant differences between organic and conventional farms were found in soil health indicators such as nitrogen mineralization, microbial abundance, organic carbon content and diversity, (Drinkwater, Letourneau, Workneh, van Bruggen, \& Shennan, 1995). The increased soil health in organic farms also led to a considerably lower disease incidence in plants.

Comparing organic and conventional fields of tomato, Drinkwater et al. (1995) concluded that yields in both systems are comparable but that crop productivity depends more on inherent soil fertility, water availability, cultivar and the management skill. Badgley et al. (2007) compared yields of organic and conventional agriculture and found no substantial yield differences in the developed world whereas, in developing nations, yields of organic agriculture surpassed those of conventional methods. This could be attributed to the robustness of organic crops during extreme climates (Lotter et al., 2003). Seufert, Ramankutty, and Foley (2012) used a comprehensive meta-analysis and found that with good management practices organic yields could match conventional yields but on average organic yields are $25 \%$ lower than their conventional counterparts.

Globally, organic production and consumption have been growing over the past decades (Willer and Lernoud, 2014). There is an upward trend in the number of farmers applying organic farming methods, in the hectares dedicated to organic agriculture, the number and variety of companies active in marketing and selling organic foods and the number of consumers of organic products. Turkey is no exception. Certified organic farming in the country started in 1986 with the production of dried fruits to export to Europe. The Turkish Parliament passed the organic farming law in December 2004 and the land allocated to organic agriculture more than quadrupled since then: from 209,573 hectares in 2004 to 883,118 hectares in 2014 (Note 2). However, most organic production of Turkey was being exported (Demiryürek, Stopes, \& Güzel, 2008) and the domestic market remained underdeveloped (Aktar \& Ananias, 2005). Studying the state of the organic sector in Turkey, Kenanoğlu and Karahan (2002), Demiryürek (2004) and Özbilge (2007) listed the reasons for the undeveloped state of the domestic market as the limited availability of organic products and of sales channels, high price premium, lack of consumer recognition and lack of government support among the constraints impeding the development of the sector, and suggest that to expand organic production further, the domestic market for organic products needs to be developed. Lehner (2009) too underlines the importance of a lively domestic market in order to decrease the risk of export dependency. All of these works emphasize the support and the sponsorship of the ministry in all stages and some argue that universities and other "knowledge creating and distributing actors" should be given a bigger role in the development of the sector. As an attempt to develop the domestic organic market, civil society organizations are collaborating with local governments to establish 
marketplaces solely for organic products. These marketplaces, located primarily in Istanbul, had a mobilizing effect on the domestic organic sector (Akyüz and Demir, 2016).

One of the claims supported by the proponents of conventional agriculture is that without conventional methods there would be starvation. They also argue that without the use of harmful chemicals or GMOs, a lot more farmland will be needed and forests will be cut down. A comprehensive document on answers to the criticisms and misconceptions about organic agriculture such as starvation can be found in (IFOAM, 2009). As Reganold and Wachter (2016), we are of the opinion that the cause of hunger is not the absence of sufficient food; the cause of hunger is the unfair distribution of wealth and of food. Because of this unfair distribution, some people go hungry whereas some people have a lot more than they need and food waste is a reality, (Stenmarck, Jensen, Quested, \& Moates, 2016). Indeed, the recent work of Muller et al. (2017) reports that organic agriculture is a viable option to feed the world population in the future when combined with reductions of food wastage; consumption of animal products; and food-competing-feed from arable land. While reasons behind the hunger problem in the world are political (Lappe \& Collins, 1986) and not agricultural, organic agriculture still presents a solution by increasing yields in low-input areas, increasing income, reducing costs and providing employment for farm families; conserving bio-diversity and natural resources on the farm and in the surrounding area, and producing safe and varied food.

With the current paper, we want to contribute to the discussion above by showing that there is sufficient arable land in Turkey to feed the whole population solely with organic foods. The availability of other limited resources used in farming such as water and labor are not considered in our work. Water availability data for Turkey is not publicly available. Therefore, though water is a critical resource for farming, its availability in sufficient amounts is taken for granted in this study. Considering that organic and other environmentally friendly farming practices use water in a more sustainable and responsible manner (Reganold \& Wachter, 2016; Liebig \& Doran, 1999), we assume that the model results would not be significantly influenced by the addition of water availability data. Furthermore, the crop yield data indirectly comprise and reflect water availability as combined with climate conditions, top soil quality, etc. Another resource, not included in the model, is labor. Turkey has a relatively high proportion of young people (the first among EU and OECD countries) and a significant working-age population. Besides, throughout the history, a large portion of Turkey's population has been engaged in agriculture and the country used to be one of the few self-sufficient countries in the world until the 90s. Although the population practicing agriculture has been decreasing continually, Turkey is still considered among the top agricultural countries. Consequently, the additional labor required to convert to an all-organic Turkey is presumed to be available in this research. Finally, we assume the sufficient availability of nitrogen; a substance necessary for plant growth but whose surplus creates environmental problems. In conventional agriculture, nitrogen is provided in the form of chemical fertilizers whose use is unsurprisingly prohibited in organic agriculture due to its adverse environmental effects. In organic agriculture, nitrogen is supplied by manure, crop residues and $\mathrm{N}$-fixation from increased legume cropping. Indeed, some of the organic certification firms active in Turkey require organic farmers to reserve at least $25 \%$ of the farm land to legume cropping (V. Ersöz, personal communication, December 2017). Since legumes are valuable sources of protein included in a healthy diet for humans and some, such as alfalfa, can also be consumed by animals, we assume that this condition be easily satisfied in the agricultural plans that we produce using our model..

To show that there is sufficient arable land in Turkey to feed the whole population solely with organic foods, we developed an organic agricultural plan for Turkey by using linear programming (LP), a renowned optimization technique successful in solving large real-world problems. Specifically, we find how many acres of each crop should be grown in each of the 81 cities in Turkey so that the whole population consumes organic foods only plant-based as well as animal products-. To feed livestock and poultry, crops such as corn and barley and forages such as alfalfa are planted on arable land using organic practices. Both intensive (industrial) and extensive (grazing on meadows and pastures) methods of organic livestock production are utilized. The model incorporates transportation between cities while identifying any missing foods or excess land. Using suggestions from health experts and eating habits of Turkey's citizens, we compiled a diet providing sufficient energy and containing healthy sources of fats and carbohydrates balanced with appropriate levels of protein from organic foods. The linear programming model includes 120 crops and four animal-based products resulting in about 950 thousand variables and 40 thousand constraints. Using General Algebraic Modeling System (GAMS) as the modeling language and CBC as the LP solver, we reach an optimum solution in less than 40 seconds. Computational results indicate that there are no food shortages and that it is possible to feed a whole population with organic products using only $63 \%$ of the available arable land. By mathematically refuting the argument that it is impossible to feed the whole population with organic foods, we contribute to the removal of one obstacle on the 
way leading to the development of the domestic organic market and the widespread accessibility of organic agriculture products in Turkey. In addition, with the use of an embedded transportation module we obtain results that lower fossil fuel consumption in food delivery.

\section{Linear Programming in Agricultural Planning}

Linear programming is one of the most important tools used by industrial engineers and operations researchers. It is an optimization method to formulate and solve problems with a linear objective function and constraints in the form of linear (in)equalities. The solution process is incredibly fast taking advantage of linear algebra methods and the progress in the computing discipline. Developed by George Dantzig towards the end of World War II, linear programming has been successfully used for the solution of large scale problems. A nice history of linear programming, followed by its theory as well as references to various LP applications can be found in Dantzig and Thapa (1997).

Agriculture has been one of the application areas of linear programming, (Dent, Harrison, \& Woodford, 1986; Moss, 2002; Williams, 1999). A good source for linear optimization models in agriculture is the model library of General Algebraic Modeling System (GAMS); see Brooke, Kendrick, Meeraus, and Raman (1998) for how to access the model library. Linear programming is becoming a frequently used technique in research conducted in organic farming as well. Several farm level studies exist, for example, Acs, Berentsen, and Huirne (2007) use dynamic programming to study the conversion process of farms from conventional to organic and apply sensitivity analysis to show the effects of organic prices, depreciation and availability of labor at peak periods. Kerselaers, De Cock, Lauwers, and Van Huylenbroeck (2007) model the economic potential of farmers for conversion to organic farming. Pacini, Wossink, Giesen, and Huirne (2004) compare the economic and environmental performances of conventional farms and organic farms in Italy under different regulations and support schemes. Annetts and Audsley (2002) propose a multi-objective linear programming model to study environmental farm planning; this is a very detailed model at the farm level including crop rotation and sequencing, machine availability, land availability, and livestock grazing and feeding constraints; objectives considered are the maximization of profit and the minimization of the negative environmental effects of farming; UK data is used. An LP problem modeling the use of organic fertilizers and crop sequences to conserve and replenish the nutrients in the soil can be found in the GAMS model library, see Brooke et al. (1998). Lansink, Pietola, \& Bäckman (2002) use data envelopment analysis to compare the efficiency and productivity of conventional and organic crop and livestock farms in Finland -on average organic farms are found to be more efficient but less productive- and discuss the possible reasons behind the lower productivity of organic farms. More recently, a landscape-level model was proposed by Kennedy et al. (2016) to jointly optimize biodiversity, water quality and profit using a multi-objective model targeting sugarcane production and cattle ranching in southeastern Brazil. The work proposed by Le-Si et al. (1983) is very much related to ours in the sense that it is a linear programming model of Turkey's agricultural sector but differs from ours in many aspects. The main goal of Le-Si et al. (1983) is economic growth and so they include prices, price elasticity, (linearized) demand functions, import and export quantities; which we do not include in our model. In contrast, our main goal is to achieve a healthy human, animal and plant population as well as preserve soil fertility, water quality and clean air. Therefore, we provide an organic agriculture plan for the country prescribing which crop or animal to grow in every city, a detail which Le-Si et al. (1983) omit. The resulting plan from our work is a step towards ensuring food security and food sovereignty of the country, respecting nature, biodiversity and providing fair working conditions for farmers and farm families. At this point, the work of Jacobson et al. (2017) is worth mentioning who provide a roadmap for 139 countries of the world to convert all energy use to $100 \%$ water, wind and sun powered technologies. Ours is also a holistic model prescribing that all arable land to be converted to organic agriculture. They argue that in their case $100 \%$ conversion is possible economically and technically but that the barriers would be social and political. We show here mathematically that feeding a country with $100 \%$ organic foods is possible while expecting barriers of a similar nature.

\section{Developing Turkey's Organic Agriculture Plan}

Our goal is to feed the whole population of Turkey with organic products only and in this section, we present a linear programming formulation of an organic agriculture plan at the country level. This is in contrast with most of the models mentioned in the above paragraph that are at the farm level. Figure 1 is a visualization of data requirements and summary of outputs. 


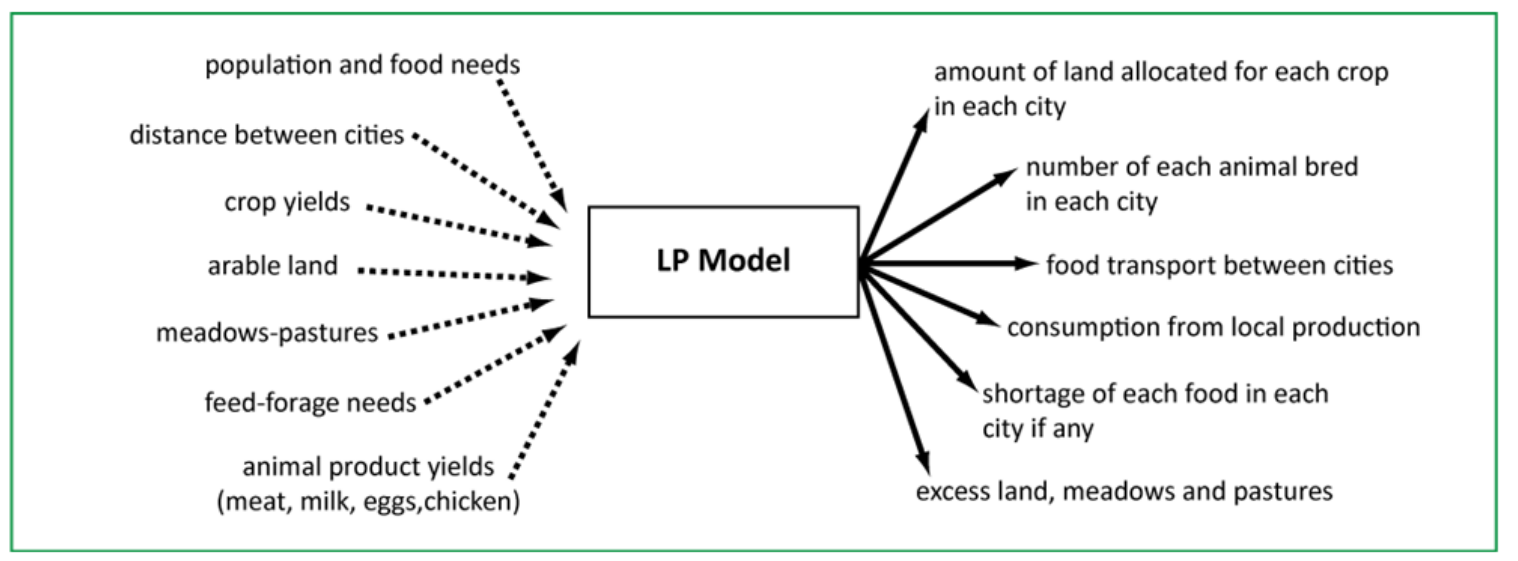

Figure 1. Inputs and Outputs of the LP Model

Main inputs of the mathematical model are:

- a menu containing a variety of foods,

- the list of crops to be grown for human consumption,

- the list of feed and forage crops to be grown,

- the crop yields under organic farming,

- the amounts of arable land, meadows and pastures in each city,

- the list and quantities of animal products to be consumed,

- the different animal species traditionally bred in the country, and

- the product (such as milk or meat) yields of these animals.

Some of the data, we easily obtained from websites of government agencies: (i) the distances between cities from the General Directorate of Highways of Turkey [KGM] (2014), (ii) the geographic distribution of the population from the Turkish Statistical Institute [TUIK] (2014a), and (iii) the amount of arable land from TUIK (2014b). The rest of the above-mentioned inputs required more effort to obtain. In the following, we discuss these in more detail while specifying sources used to extract them.

\subsection{Data Requirements: a Balanced Nutritious Diet}

After modeling the constraints and the objective function of the mathematical model that we report in Section 3.4 , to run our program and obtain results, we needed the values of a variety of input parameters. One such input to the LP model is the list and quantities of products to be consumed by one individual in a year. In a balanced nutritious diet, an individual has to consume fresh fruits and vegetables, good sources of carbohydrates and fats and a certain amount of protein. Depending on the activity level, age and physical size, the daily energy requirement can be anywhere between 1000-3200 kcal (Note 3). The percentage ranges for a healthy diet, (Lichtenstein et al. 2006), recommend that calories from protein range in (10-35\%), those from carbohydrates in (45-65\%) and calories from fat in (20-35\%) which can surpass $40 \%$ when a Mediterranean type diet is consumed with healthy sources of fat such as olive oil (Kafatos, Verhagen, Moschandreas, Apostolaki, \& Van Westerop, 2000). Indeed, in the model, the fat consumed comes from four sources: olive oil (52\%), nuts (11\%), animal products (14\%), and other plants (23\%). To curb appetite and control weight gain we used a slightly larger fraction of calories from proteins than that in the standard diet, (Pesta \& Samuel 2014).

Due to the rich biodiversity of the country, Turkey's citizens are used to consuming a wide variety of products. In the model, we made an effort to include the most frequently consumed plants and animal products. Appendix A contains a detailed list of 106 crops for human consumption, 4 animal products, 7 feed crops and 12 forage crops used in the model. For an average person we use a $2400 \mathrm{kcal}$ diet with 90 grams of fat, 272 grams of carbohydrates and 91 grams of protein. These quantities fall into the percentage ranges recommended by health experts. The calorie level of $2400 \mathrm{kcal}$ is high for a young child and low for individuals who work at physically demanding jobs and need to consume a large amount of calories, but, when averaged, there will be ample food for every citizen to remain healthy. In Table 1, we provide the list and quantities of foods consumed, grouped into main categories. 
Table 1. Main food groups and consumption levels

\begin{tabular}{llllllllllll}
\hline Food group & \multicolumn{1}{c}{ Legumes Grains Vegetables Greens Fruits Olives** } & Meat & Chicken Milk*** Eggs Nuts \\
\hline Consumption* & 100 & 200 & 300 & 250 & 400 & 250 & 30 & 40 & 364 & 260 & 20 \\
\hline
\end{tabular}

* All quantities in the table except eggs are daily figures in grams; for eggs, annual consumption is given in units.

**25 gr olives to be consumed at breakfast and 225 gr converted to olive oil, making approximately $32 \mathrm{gr}$ olive oil (conversion ratio of olives to olive oil is 7:1) to be used for cooking and on salads.

***We assume that an individual consumes $25 \mathrm{gr}$ cheese (conversion ratio of milk to cheese is 8:1), 100 gr yoghurt (conversion ratio of milk to yoghurt is 1.4:1) and 24 gr of milk daily, resulting in an equivalent of 364 gr milk.

\subsection{Data Requirements: Crops and Yields}

After deciding on the plants to be included in the model, we needed to compute the yield of each crop in each city when grown under organic farming conditions. Turkish Statistical Institute (TUIK) publishes past data regarding crop production using conventional farming methods in Turkey (Note 4). Data are detailed; one can find location information ranging from country level down to municipalities. Individual crops are listed as well as food groups together with quantity produced and the amount of land cultivated. Unfortunately, such data are not available for organic products. For organics, data published only list the amount produced but not the amount of cultivated land for individual crops, vital piece of information to compute organic crop yields. Employees at the Ministry of Food, Agriculture and Livestock were very helpful and we are grateful for all their support but the information provided by them was too limited to be used in research. To obtain yield information for each crop, we used conventional farming yield data published by TUIK together with the results of research comparing organic and conventional yields. Although there exist many articles arguing that organic yields get very close to their conventional counterparts and even surpass them, (Badgley et al., 2007; Drinkwater et al., 1995; Liebig and Doran, 1999; Lotter et al., 2003), to be on the safe side, we used a certain decrement in yields when organic farming methods are used. Specifically, we used the average results reported by Seufert et al. (2012), a comprehensive meta-analysis which reported that overall, organic yields are $25 \%$ (in the $5-34 \%$ range) lower than conventional with organic performance varying widely over crop types, species and practices used. We made the necessary reductions in the yields of crops, reported in Table 2.

Table 2. Average yield reductions reported in Seufert et al. (2012)

\begin{tabular}{lccccccc}
\hline Food group & Fruits and nuts & Grains & Wheat & Vegetables & Legumes & Tomato & Salad greens \\
\hline Reduction percentage & $10 \%$ & $25 \%$ & $40 \%$ & $30 \%$ & $10 \%$ & $20 \%$ & $25 \%$ \\
\hline
\end{tabular}

To increase modeling complexity at a reasonable pace, we first formulated a vegetarian model. In this model, all citizens of the country consume only plants. In order to account for the loss of animal protein, we increased the daily intake of legumes and grains. Using the most frequently consumed 106 crops and 81 cities resulted in about 750 thousand variables and 28 thousand constraints. We found the optimal solution in less than 30 seconds. The results showed that $54 \%$ of the arable land in Turkey sufficed to provide the necessary nutrition (2330 calories, $83 \mathrm{gr}$ protein, $69 \mathrm{gr}$ fat, and $297 \mathrm{gr}$ carbohydrates) to the whole population in the form of organic foods. In the second model, we included organic animal products to allow for a more diverse diet. We report the details of the omnivore model in Sections 3.3 and 3.4.

\subsection{Data Requirements: Modeling Animal Products}

In this paper, our main concern is the availability of sufficient arable land to feed the population. Therefore, in what follows, we only consider the feed needs of animals as they affect the amount of arable land. Organic farming rules and regulations that are in effect in Turkey prescribe several other conditions for raising animals; these concern the amount of living space to be allotted to each individual animal, the access to outdoors, exposure to natural lighting etc. These conditions are of a more technical nature and can be satisfied without a burden on arable land.

A difficulty in modeling was the dual role of animals. Once, their products are food items for humans, then again, animals themselves are consumers of plants that were grown on the same arable land used for growing plants for human consumption. Hence by defining appropriate variables in the model, (i) we determine how many of each animal we need to raise to feed the human population, and (ii) we allot certain amount of arable land to satisfy the feed needs of these animals. Animals modeled are beef cattle, dairy cows, and two breeds of chicken, for meat and eggs. Although there are a number of different sheep and goat breeds in Turkey, we have not included 
them in our model to keep data processing efforts at a reasonable level (Note 5).

\subsubsection{Chicken and Eggs}

In the model, we included two general breeds of chicken: broilers, those raised for their meat and egg-laying chicken, each with a different lifetime and meat/egg yields. To feed both types of chicken, main feed products used are soy and corn. Lampkin (1997) suggest that corn-fed table birds may be fed a ration containing a minimum of $65 \%$ cereals and if corn is used, it should make up at least $50 \%$ of the ration. For laying hens, Zollitsch and Baumung (2004) suggest a 100\% organic diet consisting of 50\% corn, $35 \%$ soybean or sunflower, $5 \%$ alfalfa and $10 \%$ minerals. In the model, we used feed rations from an organic poultry farm in the Agean part of Turkey. There, broilers consume 8.75 kilograms of total feed during their lives whereas egg-laying chicken daily consume 54 grams in the first 15 weeks of their lives and 130-140 grams in the remaining 75 weeks. Using these figures, we computed total annual soy and corn consumption of each chicken breed. The feed rations and product yields are summarized in Table 3. These quantities are in accordance with the percentages suggested in the literature.

Table 3. Yield and feed needs of chicken

\begin{tabular}{llllll}
\hline & Lifetime & Yield & $\begin{array}{l}\text { Soy } \\
\text { content }\end{array}$ & $\begin{array}{l}\text { Corn } \\
\text { content }\end{array}$ & $\begin{array}{l}\text { Vitamins, minerals } \\
\text { and stone }\end{array}$ \\
\hline Broiler & $\geq 81$ days & $\begin{array}{l}\text { At the end of their lives: } 2.5 \mathrm{~kg} \text { live weight } \\
\text { becomes 1.7 kg of chicken meat }(68 \% \\
\text { carcass yield). }\end{array}$ & $70 \%$ & $5 \%$ \\
\hline $\begin{array}{l}\text { Egg-laying } \\
\text { chicken }\end{array}$ & $\approx 90$ weeks & $\begin{array}{l}\text { With no eggs in the first 15 weeks, 260 } \\
\text { eggs are produced annually (Note 6). }\end{array}$ & $29 \%$ & $56 \%$ & $15 \%$ \\
\hline
\end{tabular}

Source: (E. Çetinkol, personal communication, January 10, 2015)

\subsubsection{Milk and Beef Cows}

There are two fundamentally different methods of cattle breeding: intensive and extensive.

Table 4. Animal breeds, regions and yields

\begin{tabular}{|c|c|c|c|c|c|}
\hline Type & Region & $\begin{array}{l}\text { Average } \\
\text { annual milk } \\
\text { yield }(\mathrm{kg})\end{array}$ & $\begin{array}{l}\text { Average life } \\
\text { weight - adult } \\
\text { female }(\mathrm{kg})\end{array}$ & $\begin{array}{l}\text { Average life } \\
\text { weight - adult } \\
\text { male }(\mathrm{kg})\end{array}$ & $\begin{array}{l}\text { Carcass } \\
\text { ratio } \\
(\%) \\
\end{array}$ \\
\hline Yerli Kara & Central Anatolia & 1062 & 200 & 300 & 57 \\
\hline Kilis Bahçe & South East Anatolia & 1875 & 414 & 610 & 60 \\
\hline Yerli Sarı* & $\begin{array}{l}\text { Eastern and northern parts of } \\
\text { Mediterranean }\end{array}$ & 633 & 200 & 300 & 57 \\
\hline Boz Step & $\begin{array}{l}\text { East Marmara, Thrace, } \\
\text { North Aegean and west parts } \\
\text { of Central Anatolia }\end{array}$ & 1096 & 375 & 470 & 57 \\
\hline $\begin{array}{l}\text { Doğu Anadolu } \\
\text { Kırmızıs1 }\end{array}$ & East Anatolia & 939 & 322 & 393 & 61 \\
\hline Manda Camış & $\begin{array}{l}\text { All parts of Turkey but } \\
\text { mainly the Blacksea region. }\end{array}$ & 925 & 438 & 438 & 55 \\
\hline Zavot & $\begin{array}{l}\text { Kars (city in East Anatolia) } \\
\text { and vicinity }\end{array}$ & 2300 & 400 & 550 & 57 \\
\hline $\begin{array}{l}\text { Intensive beef cattle } \\
\text { and milk cows }\end{array}$ & All parts of Turkey. & 5000 & 500 & 650 & 60 \\
\hline
\end{tabular}

*We used data from Yerli Kara to fill the missing data pieces of Yerli Sarı, similarly for the weight of male Manda we used the figures for female Manda.

In the extensive method, also called traditional, animals freely graze on meadows and pastures as long as climate and grass conditions allow. The farmer provides a roof under which the animals can seek shelter when the weather gets rough (either too cold and stormy or too hot and sunny). The shelter can also be in the form of a group of densely grown appropriate trees. When weather or grass conditions are ill-suited for grazing, the farmer provides grass, hay or forages that have been cut and dried for this purpose at the time of harvest (S. Beyazit, personal communication, February 2015; Younie, 2001, Voisin, 1959). In the intensive method, animals are kept indoors 
apart from a small grazing area and the farmer provides all of their feed needs. Mete Hacaloğlu criticized that organic intensive animal husbandry differs from conventional animal husbandry in only a single aspect: the feeds used are organically grown. From an optimistic perspective, this means that it is relatively simple to convert from conventional intensive animal husbandry to an organic method (personal communication, February 2015). Details regarding the locality, milk and meat yields of the animals are inputs to the mathematical model in Section 3.4. This information, mainly compiled from Meat\&Milk Board [MMB] (2015) and the Official Gazette of the Republic of Turkey [OGTR] (2004), is summarized in Table 4.

\subsubsection{Extensive Animal Husbandry: Feed Needs}

The extensive method has long been the traditional animal husbandry technique used in Turkey with several local breeds of both beef cattle and milk cows. In feeding cattle using the extensive method, we did not distinguish between milk cows and beef cattle but acknowledged a seasonal differentiation. Cattle, when grazing in a meadow in ideal conditions ( $15 \mathrm{~cm}$ grass height), daily consume green grass that amounts to at most $10 \%$ of their body weights (Voisin, 1959) (Note 7). On meadows and pastures in average conditions, the cows graze an equivalent of at most $8.5 \%$ of their body weights, daily (Voisin, 1959 p. 77). For a Zavot of $550 \mathrm{~kg}$, that means a daily consumption of $46.75 \mathrm{~kg}$ of forage, making a total annual consumption of $17064 \mathrm{~kg}$ green forage. A portion of this annual figure is obtained by grazing. Each city has a certain amount of meadows and pastures with different dry fodder yields; we have used these as inputs to the mathematical model. However, when meadows or climate conditions do not allow for grazing, the farmer provides the remaining amount in the form of dry forage. Forages common to Turkey are alfalfa (medicago sativa), common vetch (vicia sativa), sainfoin (onobrychis sativa), oat (avena), grasspea (lathyrus), wheat (triticum), sorghum, bitter vetch (vicia ervilia), barley (hordeum vulgare), rye (secale cereale) and crimson clover (trifolium incarnatum). We have observed that alfalfa is grown in almost all cities in Turkey except a few; for example in Rize only barley is grown, similarly in Mardin, grass pea, bitter vetch and common vetch are used as forages. In the model, instead of forcing a diet containing a specific forage crop such as alfalfa, we allowed traditional forages common to each city to be used for supporting animal nutrition when necessary, see Section 3.4 equation (10). Using 2014 data from United States, Kniss, Savage, and Jabbour (2016) report that as a group, organic hay crops yield similarly or better than conventional hay crops (Note 8). Since the experience of organic livestock farmers in Turkey is similar (M. Hacaloğlu, personal communication, February 2015), we used conventional yields without making any reduction when computing the yields of forage crops under organic farming.

\subsubsection{Intensive Animal Husbandry: Feed Needs}

To summarize the feed needs of cattle, the term ration is used in the intensive method. Rations for beef cattle are different from those for milk cows, (Görgülü, 2002). In the model, we simplified real life and used one species of beef cattle and one species of milk cow to represent the average animal under intensive management. One can think of this average animal as a Holstein or a Simental or a crossbreed of these with one of the local cattle species. Feeds used in the intensive method are classified as roughage and concentrate feed. Roughage consists of fresh and dry hay, forages and silage whereas concentrate feed mainly consists of grains and legumes. In organic animal husbandry, additives are tightly controlled and restricted but some vitamins can be added to the feeds (Özen, Şayan, Ak, Yurtman, \& Polat, 2010).

In feeding milk cows, it is suggested to have a high ratio of roughage (A. Sökmen, personal communication, 2014) and provided that it is kept very high for lactating cows, this ratio should be at least $60 \%$ (Ministry of Food, Agriculture and Livestock [MFAL], 2017). Same document also states that $3 \mathrm{~kg}$ of silage is equivalent to $1 \mathrm{~kg}$ of dry feed. In the model, we used feed rations from an organic dairy farm where roughage to concentrate ratio is on average $77 \%$. To obtain the necessary annual feed need figures, we assumed that a milk cow's life lasts 7 years, the first two years of these are spent first as a calf then as a heifer without lactating, and in the next five years, the cow is lactating and goes through different stages in terms of milk yield and nutritional needs during lactation. We assumed that on average, a milk cow under intensive management consumes daily $1.2 \mathrm{~kg}$ of barley, $1.7 \mathrm{~kg}$ of corn, $15 \mathrm{~kg}$ corn silage, $1 \mathrm{~kg}$ soy, $3.3 \mathrm{~kg}$ dry alfalfa and $3 \mathrm{~kg}$ wheat straw (M. Hacaloğlu, personal communication, February 2015). Using these figures, we computed her annual average need of each feed crop: $426 \mathrm{~kg}$ barley, 606 $\mathrm{kg}$ corn, $5655 \mathrm{~kg}$ corn silage, $372 \mathrm{~kg}$ soy, $1207 \mathrm{~kg}$ dry alfalfa (medicago sativa) and $1095 \mathrm{~kg}$ wheat straw (Note 9). Noticing that wheat straw is a by-product and its need can be satisfied from wheat grown for human consumption we only added decision variables that represent the amounts of barley, corn, soy, corn silage and alfalfa to be grown in each city.

Nutrition of beef cattle raised using the intensive method differs from that of milk cows greatly, especially in terms of protein content. Organic cattle farms suggest that organic beef cattle on average consume $4 \mathrm{~kg}$ of barley, $2.5 \mathrm{~kg}$ 
of corn, $2.5 \mathrm{~kg}$ of soy, $1.22 \mathrm{~kg}$ of dry alfalfa and $3 \mathrm{~kg}$ of wheat straw daily (Mete Hacaloğlu, personal communication, April 2015). Usually beef cattle are slaughtered around 15-18 months of age so they need to gain weight quickly. Therefore, the concentrate ratio in the feed mix is higher than that of milk cows, it is at least $60 \%$ and reaches $100 \%$ at the end of their lifetimes (Uğur, 2004; Younie, 2001). In the mathematical model, we kept the concentrate ratio for intensive beef cattle at $68 \%$ on average.

\subsection{Components of the LP Model}

Following the list of index sets and the definition of parameters and decision variables in Table 5, we present the main constraints and the objective function(s) of the problem.

Table 5. Index sets, variables and parameters

\begin{tabular}{|c|c|}
\hline \multicolumn{2}{|l|}{ Index sets } \\
\hline$P$ & set of all organic crops grown for human and animal consumption \\
\hline$F$ & subset of $P$, set of organic feed products for chicken and livestock including grass \\
\hline$L$ & set of organic animal products for human consumption \\
\hline$H$ & subset of $P$, set of organic forage products grown on arable land \\
\hline$A$ & set of animal types bred using organic practices \\
\hline$C$ & set of cities \\
\hline \multicolumn{2}{|l|}{ Parameters } \\
\hline$\overline{D_{j k}}$ & distance between cities $j$ and $k$ \\
\hline Agrland $_{j}$ & amount of arable land in city $j$ (decares) \\
\hline $\mathrm{Pop}_{i}$ & population of city $j$ \\
\hline FoodReq $_{i}$ & annual requirement of one person of food $i$ (both plant and animal products) \\
\hline$F e e d N_{h i j}$ & annual need for feed $i$ of one animal $h$ in city $j$ \\
\hline ForageN $_{h j}$ & annual forage need of one animal $h$ in city $j$ \\
\hline$M e a d w_{j}$ & Amount of meadows in city $j$ (decares) \\
\hline GrassNeed $_{h j}$ & annual grass need of one animal $h$ in city $j$ (grazing) \\
\hline Grassyield $_{j}$ & fresh grass yield of meadows and pastures in city $j$ ( $\mathrm{kg} / \mathrm{decare})$ \\
\hline Yield $_{i j}$ & yield of crop $i$ in city $j$ under organic farming conditions ( $\mathrm{kg} / \mathrm{decare})$ \\
\hline Cmeatyield $_{h j}$ & average annual chicken meat production capacity of animal $h$ in city $\mathrm{j}$ \\
\hline Eggyield $_{h j}$ & average annual egg production capacity of animal $h$ in city $\mathrm{j}$ \\
\hline Meatyield $_{h j}$ & average annual meat production capacity of animal $h$ in city $\mathrm{j}$ \\
\hline Milkyield $_{h j}$ & average annual milk production capacity of animal $h$ in city $\mathrm{j}$ \\
\hline$S C$ & Shortage cost of food \\
\hline$T C_{i}$ & unit transportation cost for food type $i$ per shipment \\
\hline \multicolumn{2}{|l|}{ Variables } \\
\hline $\bar{Z}$ & total distance travelled by food and costs of transportation, shortages and agriculture \\
\hline$x_{i j}$ & amount of arable land allocated for growing crop $i$ in city $j$ (decares) \\
\hline$a_{h j}$ & number of animals of type $h$ bred in city $j$ \\
\hline$p_{i j}$ & amount of food type $i$ (in $\mathrm{kg}$ ) produced in city $j$ \\
\hline$c_{i j}$ & amount of food type $i$ (in $\mathrm{kg}$ ) consumed in city $j$ \\
\hline$y_{i j}$ & amount of food type $i$ (in $\mathrm{kg}$ ) produced in city $j$ and consumed in the same city \\
\hline$t_{i j k}$ & kilograms of food type $i$ transported from city $j$ to city $k$ \\
\hline$s_{i j}$ & kilograms of food type $i$ in shortage in city $j$ \\
\hline$e l_{j}$ & excess land in city $j$ (decares) \\
\hline $\boldsymbol{e p m}_{j}$ & excess meadows and pastures in city $j$ (decares) \\
\hline$p u_{j}$ & percent land used in city $j$ \\
\hline$c g_{j}$ & amount of leftover pastures in city $j$ cut to be used indoors (decares) \\
\hline
\end{tabular}

\subsubsection{The Mathematical and Logical Restrictions of the Problem}

In LP terminology, the mathematical and logical restrictions of a real world problem are called constraints. The main constraints are given as:

$$
\begin{gathered}
\boldsymbol{p}_{\boldsymbol{i}, \boldsymbol{j}}=\boldsymbol{x}_{\boldsymbol{i}, \boldsymbol{j}} \cdot \text { Yield }_{i j} \text { for } i \in P \backslash\{\text { Grass }\} \text { and } j \in C \\
\boldsymbol{p}_{\text {Milk,j }}=\sum_{h \in A} \text { Milkyield }_{h j} \cdot \boldsymbol{a}_{\boldsymbol{h}, j} \text { for } j \in C \\
\boldsymbol{p}_{\text {Meat }, j}=\sum_{h \in A} \text { Meatyield }_{h j} \cdot \boldsymbol{a}_{\boldsymbol{h}, j} \text { for } j \in C
\end{gathered}
$$




$$
\begin{aligned}
& \boldsymbol{p}_{\text {Chicken }, j}=\sum_{h \in A} \text { Cmeatyield }_{h j} \cdot \boldsymbol{a}_{\boldsymbol{h}, \boldsymbol{j}} \text { for } j \in C \\
& \boldsymbol{p}_{\text {Eggs }, j}=\sum_{h \in A} \text { Eggyield }_{h j} \cdot \boldsymbol{a}_{\boldsymbol{h}, j} \text { for } j \in C \\
& \boldsymbol{y}_{i, j}=\boldsymbol{p}_{i, j}-\sum_{k \neq j} \boldsymbol{t}_{i, j, k} \text { for } i \in(P \cup L) \backslash\{\text { Grass }\} \text { and } j \in C \\
& \boldsymbol{c}_{\boldsymbol{i}, \boldsymbol{j}}=\boldsymbol{y}_{i, j}+\sum_{k \neq j} \boldsymbol{t}_{i, \boldsymbol{k}, \boldsymbol{j}} \text { for } i \in(P \cup L) \backslash\{\text { Grass }\} \text { and } j \in C \\
& \boldsymbol{c}_{\boldsymbol{i}, \boldsymbol{j}}+\boldsymbol{s}_{i, j}=\text { Pop }_{j} \cdot \text { FoodReq }_{i} \text { for } i \in(P \cup L) \backslash(F \cup H) \text { and } j \in C \\
& \boldsymbol{c}_{\text {Grass }, j^{j}}=\left(\text { Meadw }_{j}+\text { Pastur }_{j}-\text { epm }_{j}-\boldsymbol{c g}_{j}\right) \cdot \text { Grassyield }_{j} \text { for } j \in C \\
& \sum_{i \in H}\left(\boldsymbol{c}_{i, j}+\boldsymbol{s}_{i, j}\right)+\boldsymbol{c g}_{j} \cdot \text { Grassyield }_{j}=\sum_{h \in A}\left(\text { ForageN }_{h j} \cdot \boldsymbol{a}_{\boldsymbol{h}, j}\right) \text { for } j \in C \\
& \boldsymbol{c}_{\boldsymbol{i}, \boldsymbol{j}}+\boldsymbol{s}_{i, j}=\sum_{h \in A}\left(\text { FeedN }_{h i j} \cdot \boldsymbol{a}_{\boldsymbol{h}, j}\right) \text { for } i \in F \text { and } j \in C \\
& \sum_{i \in P} \boldsymbol{x}_{i, j}+\boldsymbol{e l}_{j}=\text { Agrland }_{j} \text { for } j \in C \\
& \boldsymbol{p} \boldsymbol{u}_{j}=1-\boldsymbol{e l}_{\boldsymbol{j}} / \text { Agrland }_{j} \text { for } j \in C
\end{aligned}
$$

Constraints (1) relate the amount of land cultivated for each crop, $\boldsymbol{x}_{i, j}$, to the amount of production, $\boldsymbol{p}_{i, j}$, using organic farming yields, Yield $i j$. Grass is excluded from (1) because it is not "produced" on arable land but on meadows and pastures, modeled in (9).

Constraints (2) - (5) relate the amount of animal products produced to the number of animals grown. For example, in the case of milk, the equations compute $\boldsymbol{p}_{\text {Milk, }}$, the amount of milk produced in city $j$ using $\boldsymbol{a}_{\boldsymbol{h}, j}$, the number of animals of type $h$ bred in city $j$, and Milkyield $_{h j}$, the milk yield of animal $h$ in city $j$. Each type of animal, also depending on the locality it is commonly bred, produces a different amount of milk throughout their lives. This makes an annual amount of about $5000 \mathrm{~kg}$ of milk for intensive milk cows but only $1061 \mathrm{~kg}$ for the Yerli Kara milk cow when bred in Ankara or Aksaray, etc. Because Yerli Kara is not commonly bred in Adana, the annual milk yield of Yerli Kara in Adana is zero. So that with a two dimensional parameter, Milkyield ${ }_{h j}$, we have incorporated whether or not a certain type of animal is grown in a city as well as its annual milk yield. The remainder of the animal products is modeled similarly in (3) - (5).

Constraints (6) reserve a portion of production to be consumed locally in the same city, $\boldsymbol{y}_{i, j}$, and ship the remainder to other cities in need, $\sum_{k \neq j} \boldsymbol{t}_{i, j, \boldsymbol{k}}$. Constraints (7) then define the total amount of consumption of a product as the sum of the amount consumed from local production and the total amount received from other cities with excess, $\sum_{k \neq j} \boldsymbol{t}_{i, \boldsymbol{k}, \boldsymbol{j}}$.

Constraints (8) ensure that the food requirements of the human population in every city are met. The set $(P \cup L) \backslash(F \cup H)$ includes all crops and animal products for human consumption. Products in $(F \cup H)$ are excluded because these are either feed crops or forages that will be modeled in Constraints (10) and (11).

Grass is "produced" in the meadows and pastures and consumed by extensively bred cows via grazing. If there is any excess then that amount is either left unutilized, $\boldsymbol{e p m}_{j}$, or is cut, $\boldsymbol{c g}_{j}$, as in Constraints (9). The excess grass cut in (9) is used to supplement indoor feeding needs of extensively managed traditional local cow breeds modeled in Constraints (10). These equations also utilize different forage crops such as alfalfa grown on arable land. Here we do not prescribe which specific forage crop should be consumed; the summation in equation (10) enables an animal to consume whatever forage is grown in the locality it is bred. Constraints (11) ensure that the feed needs of chicken and intensively managed milk and beef cows are satisfied and include crops such as corn, soy and barley, as well as alfalfa grown on arable land. Grazing (outdoor feeding) needs of extensively managed traditional local cow breeds are also modeled in Constraints (11) when the index $i$ equals Grass. We use variables $\boldsymbol{s}_{\boldsymbol{i}, \boldsymbol{j}}$ in constraints (8), (10) and (11) to keep a record of shortages if there are any.

Finally, constraints (12) and (13) make sure that the amount of arable land utilized does not exceed the available amount, record the actual land use and compute the percentage of arable land left unused.

\subsubsection{The Objective Function and Multi-Objective Programming}

The objective function is an important element of an LP problem and it is frequently used as a vehicle to direct the solution towards specific targets. In this section, we construct the objective function to achieve our targets. Primarily, we want to feed the whole population using organic agriculture hence we will minimize food shortages as much as possible. At the same time, we want to minimize total distance travelled by food, transportation costs incurred by farmers and avoid unnecessary crop production. Obviously, the problem on hand has a multi-objective nature.

Standard approaches to solve multi-objective optimization problems, also called lexicographic optimization, are classified as the preemptive and non-preemptive methods (Note 10). The equivalence of these approaches for the 
linear case is shown in (Sherali \& Sosyter, 1983). In the preemptive approach, objectives are optimized in turn according to their priorities. This approach is sometimes preferred because different objectives are measured in different units as well. At the end of each stage, a constraint is added to ensure that a higher priority objective function value is preserved in the subsequent stages (optimizations). In the non-preemptive method, a weight is assigned to each objective that represents its relative importance. The weighted objective functions are combined into a single objective function which then is minimized.

In our problem, we have the following objectives:

$$
\begin{gathered}
\text { minimize food shortages: minimize } \sum_{i, j} \boldsymbol{s}_{i, j} \\
\text { minimize distance travelled by food: minimize } \sum_{i, j, k} D_{j k} \cdot \boldsymbol{t}_{i, j, \boldsymbol{k}} \\
\text { minimize total actual transportation cost: minimize } \sum_{i, j, k} T C_{i} \cdot \boldsymbol{t}_{\boldsymbol{i}, \boldsymbol{j}, \boldsymbol{k}} \\
\text { minimize amount of cultivated land: minimize } \sum_{i \in P, j \in C} \boldsymbol{x}_{\boldsymbol{i}, \boldsymbol{j}}
\end{gathered}
$$

In (14) we summed the shortage variable $s_{i, j}$ and minimized total food shortage. In some cities such as Istanbul with a large population but very limited amount of arable land, food requirements cannot be met from local production; in these cases excess foods from nearby cities are transported. To prevent unnecessary transportation, distances, $D_{j k}$, are multiplied with $\boldsymbol{t}_{i, j, k}$, the variable representing the amount of food $i$ transported from city $j$ to $k$, and total distance travelled by food is computed and minimized in (15). To construct (16), actual transportation costs incurred by farmers are found by multiplying $T C_{i}$ with $\boldsymbol{t}_{i, j, k}$. Similarly to prevent unnecessary crop production, total cultivated land is found by adding variables $\boldsymbol{x}_{i, j}$ and minimized in (17).

We applied both methods of multi-objective programming. In the preemptive method, we first optimized the objective function (14) subject to constraints (1) through (13). Using the optimal OF value as a bound on total shortages together with (1) through (13), we next optimized (15). We continued in this fashion until all the objectives are optimized. In the non-preemptive method, we formed a combined objective function. Because penalizing shortages has the highest priority, we use a high weight for (14). Trying out several penalties, we found out that a weight of 1000 is sufficient to avoid food shortages in the whole country and set $\boldsymbol{S C}$ equal to 1000 (Note 11). Objectives (15), (16), and (17) are equally important with respect to each other and we used weights of 1 for each to obtain the following combined OF:

$$
\text { minimize } \mathbf{z}=S C \cdot \sum_{i, j} \boldsymbol{s}_{i, j}+\sum_{i, j, k} D_{j k} \cdot \boldsymbol{t}_{i, j, \boldsymbol{k}}+\sum_{i, j, k} T C_{i} \cdot \boldsymbol{t}_{i, j, \boldsymbol{k}}+\sum_{i \in P, j \in C} \boldsymbol{x}_{i, j}
$$

In compliance with the result of (Sherali \& Sosyter, 1983), both methods produced the same solution. We discuss the results in the next section.

\section{Discussion of Results}

The LP model presented in Section 3.4 is capable of generating a large number of numerical results. In a basic run with 2013 data, we obtained insight into the problem of devising an organic agriculture plan for Turkey. Below we share the basic points.

Turkey can satisfy the nutrition requirements of its citizens solely from organic foods grown in the country and can feed her animals solely with organic feeds and forages; $63 \%$ of total arable land in the country suffices to achieve this. There is no shortage of any food item, neither crops nor animal products. In the vegetarian model, the required arable land was only $54 \%$ of the total available.

Transportation of food between cities takes place in all scenarios. In all of them, the most "needy" city is Istanbul requiring around 7 million tons of food products to be transported from 18 other cities. More than $70 \%$ of the food transported to Istanbul are from cities such as Tekirdağ, Sakarya, Balıkesir, Çanakkale and Edirne; all of these cities are located in the Marmara Region in close proximity to Istanbul. We see the effect of the transportation module here, minimizing total transportation costs and food-kilometers led to the utilization of cities closest to Istanbul to feed this "giant" city. All cities "export" food, especially Sakarya and Tekirdağ with 2.4 and 1.7 million tons, respectively.

In the outputs of the model, we observe that meadows and pastures have completely been used up by grazing animals and extensive animal husbandry has been the preferred method to the extent that available meadows and pastures allowed. The reason for this preference is that to produce one unit of output by the extensive method, a smaller amount of input is required than the intensive method. In that sense the intensive method is a more "expensive" animal husbandry method. In LP terminology, meadows and pastures are scarce resources and that means if Turkey were to expand the amount of meadows and pastures, better and less costly agricultural plans would be found. 
When we try out different transportation cost structures, we see the tremendous effect of transportation on the solution. Because animal products require certain temperatures during delivery, transporting these is costlier. If it costs 1 TRY to transport one kilogram of crops, it costs 2, 4.5, and 7.5 TRY to transport one kilogram of milk, chicken and meat, respectively, whereas figures for eggs are given as 0.1 TRY per unit. All of these figures are close estimates of actual costs incurred that we obtained by interviews with organic farmers and officials of companies processing, marketing and transporting organic food products. Due to the contacts that the farmers have with the logistics companies, the unit transportation cost is independent of distance travelled. However, this does not reflect the true cost to the environment and therefore we also considered an objective function (OF) where food-kilometers are added to the total actual transportation costs. Table 6 reports a comparison of different transportation cost structures.

Table 6. Distance travelled by food and required arable land at optimum solution for different transportation cost structures; distance is reported as unit-kilometers for eggs and ton- kilometers for all other products

\begin{tabular}{llll}
\hline & $T C=0$ & TC = actual & TC = actual with food kilometers in OF \\
\hline plants for human consumption & 29904 million & 12752 million & 4381 million \\
chicken feed & 6401 million & 682 million & 283 million \\
cow feed & 5996 million & 434 million & 128 million \\
forages & 42943 million & 0 & 0 \\
chicken & 2483 million & 194 million & 278 million \\
eggs & 54982 million & 3814 million & 0 \\
milk & 19179 million & 1563 million & 284 million \\
meat & 1141 million & 266 million & 496 million \\
used arable land percentage & $29 \%$ & $57 \%$ & $63 \%$ \\
\hline
\end{tabular}

First, notice the obvious result (when $\mathrm{TC}=0$ ) which is still worth mentioning because it points to the trade-off between required arable land and the distance travelled by food. When we allow transportation without penalizing it, we see that crops are produced almost entirely in cities where their yields are highest and transported to all the other cities in the country. This gives rise to a very high amount of distance travelled by food but a very low amount of arable land used, only $29 \%$, to feed the whole country. Of course, we do not suggest such an approach because its high usage of fossil fuels and adverse effects on environment are obvious. Next, we considered an OF with actual unit transportation costs. This is the case in which to comply with what the farmers are experiencing, we did not take distances into account. The required arable land percentage increased to $57 \%$ and the distances traveled by food decreased in comparison to the previous case. However, this second cost structure still did not reflect the true cost to the environment and we added the total distance travelled by food to the objective function in Section 3.4 in addition to the total transportation costs incurred by farmers. Results indicate that food now travels much less and when food travels, it does so to eliminate shortages. Finally, the required arable land to feed the country increased to $63 \%$.

Next, we made a stress test and assumed that due to drought, the topsoil in central Anatolia was lost and all the arable land has become a desert that is no longer suitable for farming. Running the model under these new conditions, we obtained results that in detail prescribe where food should be grown and transported to satisfy the food needs of Turkey including the people of central Anatolia. We observed that it is still possible to feed the whole country but this time $88 \%$ of arable land is used with most of unused land being fallow land.

Recognizing the fact that the number of fruit trees cannot be increased at a level that we require in one instant, we investigated a restrictive scenario where we placed an upper bound on the number of fruit trees in the vegetarian model. Results indicated small shortages in kiwis, bananas and some berries; larger shortages in walnuts and almonds and major shortage in olive trees. This is caused by three mechanisms: (i) we ignored regional diets and forced everybody to consume berries and kiwis, etc. (ii) a large portion of the fat in the daily diet is obtained from nuts and (iii) the major fat requirement including cooking oil is satisfied from olive oil. From this scenario we can deduce that to arrive to a Turkey consuming healthy and organic foods we need to increase the number of olive trees considerably.

In the beginning of the chapter, we reported arable land percentages for the vegetarian and the omnivore models. In the vegetarian model, daily energy intake for an individual was set at $2330 \mathrm{kcal}$ and used arable land accounted to $54 \%$ of the total available. In the omnivore model, daily energy intake was set higher at $2400 \mathrm{kcal}$ and used arable land accounted to $63 \%$ of the total available. A $3 \%$ increase in the energy intake (from 2330 to $2400 \mathrm{kcal}$ ) of individuals caused a $17 \%$ increase in the required arable land. Here we do not impose a specific 
diet such as vegetarianism; however, results of our mathematical model confirm the fact that a vegetarian diet puts a lower burden on natural resources than one that includes animal products.

Finally, we made a comparison with 2013 figures reported by the Turkish Statistical Institute summarized in Table 7. In short, our model proposes to consume less meat, much less milk and chicken meat, and $20 \%$ more eggs but in a fairly distributed fashion. Professional associations of red meat producers frequently complain of the low consumption of animal products in Turkey. With the exception of eggs, our model suggests an even lower consumption. In devising the daily menu, we complied with guidelines suggested by health experts regarding the consumption of all kinds of products including animal products. Therefore, we argue that TUIK numbers for red meat, chicken meat and milk would have been more than sufficient to feed the population in a healthful manner if they were fairly distributed.

Table 7. Comparison of model results with actual consumption of animal products

\begin{tabular}{lll}
\hline & Model output & 2013 TUIK figures \\
\hline Red meat (ton) & 839513 & 996125 \\
Chicken meat (tons) & 1119351 & 1758363 \\
Milk (tons) & 10186092 & 18223712 \\
Eggs (units) & 19933644540 & 16496751178 \\
\hline
\end{tabular}

\section{Limitations, Further Research and Conclusions}

There are some limitations of our study. Firstly, mushrooms and fish have not been included in our study. These products are healthy sources of protein and we hope to include them in the future as more data becomes available regarding their production using organic methods. Mushrooms and fish are widely consumed products in Turkey and their inclusion into the proposed diet will reduce the amount of arable land required to feed the country, making the $63 \%$ in effect an upper bound on the amount of land required. Similarly; despite the high potential in Turkey, uncultivated wild food (hunted and gathered from nature) have been out of consideration.

Secondly, breeding sheep and goat is very common in Turkey and consuming their meat is known to have a number of health benefits due the specific fatty acids in the sheep meat and the leanness of the goat meat. Still, we have not included these in our model to reduce data collection and processing time. However, if there is political will to use our model for agricultural planning, some effort must be reserved for extracting the necessary input data such as grazing habits, feed needs, meat and milk yields, for sheep and goat breeds in Turkey.

In agriculture, it is commonly encountered that the output of one part of the system to be used as input to another part. For example, manure from organic livestock production acts as valuable fertilizer for crop production. To reflect such relationships inherent in agriculture, the model needs to be extended with appropriate variables. Similarly, with additional variables, the amounts of water, labor and nitrogen in the form of any extra amount of legume cropping required in the above proposed plan should be calculated and checked against available resources.

As our goal is to feed the population of Turkey, we have only planned the organic cultivation of crops for human and animal consumption. Since only $63 \%$ of arable land is used to feed the population, there is ample space for organically cultivating commodity products such as tobacco, sugar, or cotton some of which could also be exported. In the future, the model can be extended to include these additional agricultural activities using organic farming.

Some thought needs to be given to how to reflect risk factors and effects of seasonality or include different farming practices such as permaculture in the model. It would also be useful to disaggregate the 81 cities of Turkey into its 957 municipalities and produce a more detailed agricultural plan. The conventional yield data contains a few inconsistent and incorrect records and some data cleansing is necessary. We suggest that the yield information for a product to be removed or replaced by a regional average when the total amount cultivated in a year is on less than a reasonable amount in a specific locality.

In this work, we developed a large scale mathematical model to be used in agricultural planning. Bearing in mind that historically growing crops and animal husbandry used to go hand in hand and support each other, we constructed a holistic model that includes both crops and animals. To this end, we modeled intensive and extensive methods of livestock production. Recognizing the need for a healthier method of farming for the well-being of humans, animals, plants, air, water, and soil, we used organic farming data as input and produced an organic agriculture plan for Turkey. We have shown mathematically that it is possible to feed the whole 
population of Turkey with organic foods using only $63 \%$ of arable land. Data that drives the model are a determinant factor and with similar data, the same model could be used for agricultural planning of other countries or of other farming techniques. The resulting program is also a tool that can be used to understand the effects of climate change on world food production. The encouraging results of our work give us reason to hope the feasibility of feeding the whole world with healthier farming methods such as organic agriculture.

\section{Acknowledgements}

There are many people to whom we want to thank. First of all, we are grateful to Emin Çetinkol, veterinary surgeon and founder of Dami Organic Poultry Husbandry for clearly answering our technical questions regarding the life and nutrition of organically raised chicken. Many individuals in the animal husbandry sector have come forward with answers to our many questions regarding feed rations and meat and milk yields; thanks are due to Mete Hacaloğlu, Metin Akıncı, Aysun Sökmen and Saydam Beyazıt. Information on transportation costs of crops is provided by a citrus fruit producer İbrahim Balta and a pioneering organic farmer Vehbi Ersöz, we thank them. We also thank officials of Elta Ada, JD Organik, Ambar, Seyfoğlu and Polar XP for answering our questions regarding the transportation costs of animal products. Thanks are also due to Vildan Karaaslan and Erdal Süngü of the Ministry of Food, Agriculture and Livestock who provided all available data. Our student Nergis Zeynep Erdem at Istanbul Bilgi University compiled the information in Table 4, we thank her. Finally, we thank our colleague Mert Demir for making valuable suggestions that improved our presentation and model.

\section{References}

Acs, S., Berentsen, P. B. M., \& Huirne, R. B. M. (2007). Conversion to organic arable farming in The Netherlands: a dynamic linear programming analysis. Agricultural Systems, 94(2), 405-415. https://doi.org/10.1016/j.agsy.2006.11.002

Aktar, C., \& Ananias, V. (2005). Yeni bir ulusal politika: ekolojik tarım. İktisat İşletme ve Finans, 20(229), 26-32. http://dx.doi.org/10.3848/iif.2005.229.1324

Akyüz, A. A., \& Demir, A. Y. (2016). The role of a civil society organization in the development of the domestic organic market in Turkey. İ.Ü. Siyasal Bilgiler Fakültesi Dergisi, 54, 43-61. Retrieved from http://dergipark.gov.tr/iusiyasal/issue/24993/263783

Altieri, M. A., \& Rosset, P. (1996). Agroecology and the conversion of large-scale conventional systems to sustainable management. International Journal of Environmental Studies, 50, 165-185. http://dx.doi.org/10.1080/00207239608711055

Annetts, J.E., \& Audsley, E. (2002). Multiple Objective Linear Programming for Environmental Farm Planning. Journal of the Operational Research Society, 53, 933-943. http://dx.doi.org/10.1057/palgrave.jors.2601404

Badgley, C., Moghtader, J., Quintero, E., Zakem, E., Chappell, M. J., Avil'es-V'azquez, K., ... Perfecto, I. (2007). Organic agriculture and the global food supply. Renewable Agriculture and Food Systems, 22, 86-108. http:// dx.doi.org/10.1017/S1742170507001640

Barański, M, Średnicka-Tober, D, Volakakis, N, Seal, C., Sanderson, R., Stewart, G. B., ... Leifert, C. (2014). Higher antioxidant and lower cadmium concentrations and lower incidence of pesticide residues in organically grown crops: a systematic literature review and meta-analyses. British Journal of Nutrition, 112, 794-811. http://dx. doi.org/10.1017/S0007114514001366

Brooke, A., Kendrick, D., Meeraus, D., \& Raman, R. (1998). GAMS: a User's Guide, Washington DC: GAMS Development Corporation.

Cockshott, W. P., \& Cottrell, A. (1993). Towards a new socialism. Nothingham: Spokesman.

Dantzig, G. B., \& Thapa, M. N. (1997). Linear Programming: Introduction. New York: Springer.

Demiryürek. K. (2004). Organic agriculture in the world and Turkey. Journal of Agriculture Faculty HR. University, 8(3/4), 63-71.

Demiryürek, K., Stopes, C., \& Güzel, A. (2008). Organic agriculture: the case of Turkey. Outlook on Agriculture, 37, 261-267. http://dx.doi.org/10.5367/000000008787167754

Delate, K., Cambardella, C., Chase, C., \& Turnbull, R. (2015). A review of long-term organic comparison trials in the U.S. Sustainable Agriculture Research, 4(3), 5-14. http://dx.doi.org/10.5539/sar.v4n3p5

Dent, J. B., Harrison, S. R., \& Woodford, K. B. (1986). Farm Planning with Linear Programming. Sydney: Butterworths. 
Drinkwater, L. E., Letourneau, D. K., Workneh, F., van Bruggen, A. H. C., \& Shennan, C. (1995). Fundamental differences between conventional and organic tomato agroecosystems in California. Ecological Applications, 5, 1098-1112. https://doi.org/10.2307/2269357

Fukuoka, M. (1978). The one-straw revolution. Emmaus: Rodale Press.

General Directorate of Highways of Turkey. (2014). Chart of the distance between the cities. Retrieved December 11, 2014, from http://www.kgm.gov.tr/Sayfalar/KGM/SiteEng/Root/Distances.aspx

Görgülü, M. (2002). Büyük ve Kü̧̈ükbaş Hayvan Besleme, Adana: Çukurova Üniversitesi Ziraat Fakültesi Ofset Atölyesi.

Gündoğmuş. E. (2006). Energy use on organic farming: a comparative analysis on organic versus conventional apricot production on small holdings in Turkey. Energy Conversation and Management, 47, 3351-3359. https://doi. org/10.1016/j.enconman.2006.01.001

Horrigan, L., Lawrence, R. S., \& Walker, P. (2002). How sustainable agriculture can address the environmental and human health harms of industrial agriculture. Environmental Health Perspectives, 110, 445-456. https://doi. org/10.1289/ehp.02110445

Intergovernmental Panel on Climate Change. (2013). Summary for Policymakers. In: Climate Change 2013: The Physical Science Basis. Contribution of Working Group I to the Fifth Assessment Report of the Intergovernmental Panel on Climate Change [Stocker, T. F., D. Qin, G.-K. Plattner, M. Tignor, S. K. Allen, J. Boschung, A. Nauels, Y. Xia, V. Bex \& P. M. Midgley (eds.)]. Cambridge University Press, Cambridge, United Kingdom and New York, NY, USA. Retrieved September 1, 2016 from http://www.climatechange2013.org/ images/report/WG1AR5_Summary Volume_FINAL.pdf.

International Federation of Organic Agriculture Movements. (2008). Definition of organic agriculture. Retrieved, June 12, 2009, from http: //www.ifoam.org/growing_organic/definitions/doa/index.html.

International Federation of Organic Agriculture Movements. (2009). Criticisms and frequent misconceptions about organic agriculture: the counter-arguments. Retrieved, March 7, 2011, from

http://www.ifoam.org/growing_organic/1_arguments_for_oa/criticisms_misconceptions/misconceptions_in dex.html.

Jacobson, M. Z., Delucchi, M. A., Bauer, Z. A. F., Goodman, S. C., Chapman, W. E., Cameron, M. C., ...Yachanin, A. S. (2017). 100\% clean and renewable wind, water, sunlight (WWS) all-sector energy roadmaps for 139 countries of the world. Joule, 1, 1-14. http://dx.doi.org/10.1016/j.joule.2017.07.005

Jentsch, A., \& Beierkuhnlein, C. (2008). Research frontiers in climate change: effects of extreme meteorological events on ecosystems. C. R. Geoscience, 340, 621-628. https://doi.org/10.1016/j.crte.2008.07.002

Kafatos, A., Verhagen, H., Moschandreas, J., Apostolaki, I., \& Van Westerop, J. J. M. (2000). Mediterranean diet of Crete: foods and nutrient content. Journal of the American Dietetic Association, 100, 1487-1493. https://doi. org/10.1016/S0002-8223(00)00416-8

Kenanoğlu, Z., \& Karahan, Ö. (2002). Policy implementations for organic agriculture in Turkey. British Food Journal, 104, 300-318. https://doi.org/10.1108/00070700210425732

Kennedy, C. M., Hawthorne, P. L., Miteva, D. A., Baumgarten, L., Sochi, K., Matsumoto, M., ..., Kiesecker, J. (2016). Optimizing land use decision-making to sustain Brazilian agricultural profits, biodiversity and ecosystem services. Biological Conservation, 204, 221-230. https://doi.org/10.1016/j.biocon.2016.10.039

Kerselaers, E., De Cock, L., Lauwers, L., \& Van Huylenbroeck, G. (2007). Modelling farm-level economic potential for conversion to organic farming. Agricultural Systems, 94, 671-682. https://doi.org/10.1016/j.agsy.2007.02. 007

Keyder, Ç., \& Yenal, Z. (2011). Agrarian change under globalization: markets and insecurity in Turkish agriculture. Journal of Agrarian Change, 11, 60-86. https://doi.org/10.1111/j.1471-0366.2010.00294.x

Kniss, A. R., Savage, S. D., \& Jabbour, R. (2016). Commercial crop yields reveal strengths and weaknesses for organic agriculture in the United States. PloS one, 11(8), 1-16.

https://doi.org/10.1371/journal.pone.0161673

Lampkin, N. (Ed.). (1997). Organic Poultry Production. Aberystwyth: University of Wales Welsh Institute of Rural Studies.

Lansink, A. O., Pietola, K., \& Bäckman, S. (2002). Efficiency and productivity of conventional and organic 
farms in Finland. European Review of Agricultural Economics, 29, 51-65.

https://doi.org/10.1093/erae/29.1.51

Lappe, F. M., \& Collins, J. (1986). World hunger: twelve myths. New York: Groove Press.

Le-Si, V., Scandizzo, P. L., \& Kasnakoğlu, H. (1983). Turkey agricultural sector model (AGREP Division working paper, no:AGP0067, Washington, DC: World Bank). Retrieved from http://documents.worldbank.org/curated/en /630071468172441778/Turkey-agricultural-sector-model

Lehner, M. (2009). Hindrances local organic farmers are facing in the Turkish organic agricultural sector - an attempt to identify barriers and suggest ways to eliminate them (Master's thesis, Swedish University of Agricultural Sciences (SLU), Uppsala, Sweden). Retrieved from http://stud.epsilon.slu.se/666/

Lichtenstein, A. H., Appel, L. J., Brands, M., Carnethon, M., Daniels, S., Franch, H. A., ... Wylie-Rosett, J. (2006). Diet and lifestyle recommendations revision 2006: a scientific statement from the American heart association nutrition committee. Circulation, 114, 82-96. https://doi.org/10.1161/CIRCULATIONAHA.106.176158

Liebig, M. A., \& Doran, J. W. (1999). Impact of organic production practices on soil quality indicators. Journal of Environmental Quality, 28, 1601-1609. https://doi.org/10.2134/jeq1999.00472425002800050026x

Lotter, D.W., Seidel, R., \& Liebhardt, W. (2003). The performance of organic and conventional cropping systems in an extreme climate year. American Journal of Alternative Agriculture, 18, 146-154. https://doi.org/10.1079/ AJAA200345

Meat \& Milk Board. (2015). Yerli Siğır Irkları. http://www.esk.gov.tr/tr/11004/Yerli-Sigir-Irklari Accessed 17 March 2015.

Ministry of Food, Agriculture and Livestock. (2017). Büyükbaş Hayvancıllk (Slğırcılık). Earlier version retrieved August 21, 2015, from

http://www.tarim.gov.tr/HAYGEM/Belgeler/Hayvanc1lı/Büyükbaş\%20Hayvanc1l1k/2017\%20Y1l1/Büyükba ş\%20Hayvan\%20Yetiştiriciliği.pdf.

Morison, J., Hine, R., \& Pretty, J. (2005). Survey and analysis of labor on organic farms in the UK and Republic of Ireland. International Journal of Agricultural Sustainability, 3, 24-43. http://dx.doi.org/10.1080/14735903. 2005.9684742

Moss, C. B. (2002). Applied optimization in agriculture. In P. M. Pardalos \& M. G. C. Resende (Eds.), Handbook of applied optimization (pp. 957-966), New York, NY: Oxford University Press.

Muller, A., Schader, C., El-Hage Scialabba, N., Hecht, J., Isensee, A., Erb, K.-H., ... Niggli, U. (2017). Strategies for feeding the world more sustainably with organic agriculture, Nature Communications, 8(1290), 1-13. https://doi.org/10.1038/s41467-017-01410-w

Official Gazette of the Republic of Turkey. (2004). Yerli Hayvan Irk ve Hatlarının Tescili Hakkında Tebliğ. No: 004/39-25668, Date: 12.12.2004, Ankara. Retrieved March 5, 2015, from http://www.resmigazete.gov.tr/eskiler /2004/12/20041203.htm

Özbilge, Z. (2007). An analysis of organic agriculture in Turkey: the current situation and basic constraints. Journal of Central European Agriculture, 8, 213-222. http://dx.doi.org/10.5513/jcea.v8i2.454

Özen, N., Şayan, Y., Ak, İ., Yurtman, İ. Y., \& Polat, M. (2010, January). Hayvansal üretim-çevre ilişkileri ve organik hayvancllik. Paper presented at the Seventh Turkey Agricultural Engineering Technical Congress, Ankara. Paper retrieved from http://www.zmo.org.tr/resimler/ekler/e98410c45ea98ad_ek.pdf

Pacini, C., Wossink, A., Giesen, G., \& Huirne, R (2004). Ecological-economic modeling to support multi-objective policy making: a farming systems approach implemented for Tuscany. Agriculture, Ecosystems and Environment, 102, 349-364. https://doi.org/10.1016/j.agee.2003.08.010

Pesta, D. H., \& Samuel, V. T. (2014). A high-protein diet for reducing body fat: mechanisms and possible caveats. Nutrition \& Metabolism, 11, 53. https://doi.org/10.1186/1743-7075-11-53

Reganold, J. P., \& Wachter, J. M. (2016). Organic agriculture in the twenty-first century, Nature Plants, 2, 1-8. https://doi.org/10.1038/nplants.2015.221

Rembiałkowska, E. (2007). Quality of plant products from organic agriculture. Journal of the Science of Food and Agriculture, 87, 2757-2762. https://doi.org/10.1002/jsfa.3000

Rosenzweig, C., Iglesius, A., Yang, X. B., Epstein, P. R., \& Chivian, E. (2001). Climate change and extreme 
weather events - Implications for food production, plant diseases, and pests. Global Change \& Human Health, 2, 90-104. http://dx.doi.org/10.1023/A:1015086831467

Seufert, V., Ramankutty, N., \& Foley, J.A. (2012). Comparing the yields of organic and conventional agriculture. Nature, 485, 229-232. https://doi.org/10.1038/nature11069

Sherali, H. D., \& Sosyter, A. L. (1983). Preemptive and nonpreemptive multi-objective programming: relationships and counterexamples. Journal of Optimization Theory and Applications, 39(2), 173-186. https://doi.org/10. 1007/bf00934527

Stenmarck, Å., Jensen, C., Quested, T., \& Moates, G. (2016). Estimates of European food waste levels [Report]. Retrieved from

https://www.eu-fusions.org/phocadownload/Publications/Estimates\%20of\%20European\%20food\%20waste $\% 20$ levels.pdf

Stolze, M., Piorr, A., Häring, A. M., \& Dabbert, S. (2000). Environmental impacts of organic farming in Europe. Karlsbad-Ittersbach: Hago Druck \& Medien.

Turkish Statistical Institute (2014a) Population of provinces by years. Retrieved from http://www.turkstat.gov.tr

Turkish Statistical Institute (2014b) Agricultural land by provinces. Retrieved from http://www.turkstat.gov.tr

Uğur, F. (2004). Sığır Yetiştirme. Çanakkale: Çanakkale Onsekiz Mart Üniversitesi Yayınları.

Voisin, A. (1959). Grass Productivity. Washington DC: Island Press.

Willer, H., \& Lernoud, J. (2014). The World of Organic Agriculture - Statistics and Emerging Trends 2014. FiBL-IFOAM Report. Rheinbreitbach: Medienhaus Plump.

Williams, H.P. (1990). Model Building in Mathematical Programming. Chichester: John Wiley \& Sons.

Younie, D. (2001). Organic and Conventional Beef Production - a European Perspective, Paper presented at 22nd Western Nutrition Conference, University of Saskatchewan, Saskatoon, Canada.

Zollitsch, W., \& Baumung, R. (2004). Protein supply for organic poultry: options and shortcomings. In M. Hovi, A. Sundrum and S. Padel (Eds.), Organic livestock farming: potential and limitations of husbandry practice to secure animal health and welfare and food quality: Proceedings of the 2nd SAFO Workshop (pp.153-159). Witzenhausen, Germany: The University of Reading.

\section{Notes}

Note 1. In 2008, IFOAM adopted the following definition: "Organic Agriculture is a production system that sustains the health of soils, ecosystems and people. It relies on ecological processes, biodiversity and cycles adapted to local conditions, rather than the use of inputs with adverse effects. Organic Agriculture combines tradition, innovation and science to benefit the shared environment and promote fair relationships and a good quality of life for all involved."

Note 2. Report of the General Directorate of Plant Production - Ministry of Food, Agriculture and Livestock available at: http://www.tarim.gov.tr/sgb/Belgeler/SagMenuVeriler/BUGEM.pdf

Note 3. National Heart Lung and Blood Institute:

http://www.nhlbi.nih.gov/health/educational/wecan/healthy-weight-basics/balance.htm

Note 4. https://biruni.tuik.gov.tr/bitkiselapp/bitkisel.zul

Note 5. There are 24 domestic sheep and five domestic goat breeds in Turkey, for more information, see http://www.tarim.gov.tr/Konular/Hayvancilik/Kucukbas-Hayvancilik/Koyun-Yetistiriciligi and http://www.tarim.gov .tr/Konular/Hayvancilik/Kucukbas-Hayvancilik/Keci-Yetistiriciligi

Note 6. In conventional agriculture, annual egg yield of a chicken is $315 \pm 10$.

Note 7. Whatever the meadow conditions, the cow was observed to graze no more than 8 hours a day.

Note 8. Hay crops are forages used for hay making.

Note $9.1207 \mathrm{~kg}$ dry alfalfa is equivalent to $6036 \mathrm{~kg}$ fresh alfalfa because when fresh forage is dried it loses about $80 \%$ of its weight.

Note 10. In the case of multiple goals, the approach adopted is goal programming. Goals are expressed as 
constraints; the deviations from the goals are then minimized. In our problem, we have objectives rather than goals and for that reason we use multi-objective programming and not goal programming.

Note 11. A shortage penalty of 100 instead of 1000 caused shortages in certain products and cities. If shortage occurs with the first penalty used, we advise the researcher to persist trying out several penalties until an appropriate one is found. Sometimes, the reason we have shortage is not because shortage is inevitable but because the optimization program found it cheaper to have shortages instead of transporting food between cities. Trying a larger shortage penalty will solve this problem.

\section{Appendix: List of Products and their Classifications used in the Model}

A lot of data went into the model. Population sizes of cities; distances between cities; the amount that an individual consumes of each food item; crop yields in every city under organic farming; amount of arable land, meadows and pastures in every city; the list of different animal species traditionally bred in the country; and the product yields of these animals together with their localities. To give an idea of data requirements, we provide the lists of crops for human consumption and the list of feed and forage crops, below in table format.

Tables are according to a specific classification of crops into grains, legumes, vegetables, greens and salad ingredients, fruits, nuts and olives that we used in devising a healthy menu for humans. Because only cow milk, beef, eggs and chicken meat are used as animal products in the model we did not make a separate table for those.

Table A1. Grains

\begin{tabular}{llllll}
\hline Barley Corn & Oat & Rice & Rye & Wheat & Wheat-durum \\
\hline
\end{tabular}

Table A2. Legumes

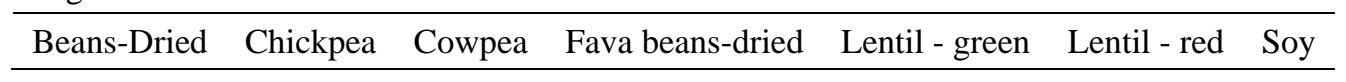

Table A3. Olives

Olive-for oil Olive-to eat

Table A4. Nuts

Almond Chestnut Hazelnut Peanut Pistachio Pumpkin-kernel Sesame Sunflower seeds Walnut

Table A5. Vegetables

\begin{tabular}{lllll}
\hline Artichoke & Carrot & Garlic & Okra & Potato \\
\hline Beans-Fresh & Cauliflower & Green beans & Onion & Pumpkin \\
\hline Beet & Celery & Kidney bean & Pea-Fresh & Spinach \\
\hline Broccoli & Chard & Leaf cabbage & Pepper-for paste & Tomato-for paste \\
\hline Brussel sprouts & Cowpea-Fresh & Leek & Pepper-to stuff & Zucchini \\
\hline Cabbage & Eggplant & & & \\
\hline
\end{tabular}

Table A6. Greens and salad ingredients

\begin{tabular}{llllll}
\hline Arugula & Cucumber-for pickling & Green onion & Mint & Purslane & Romaine lettuce \\
\hline Cress & Dill & Horseradish & parsley & Radish-red & Thyme \\
\hline Cucumber & Garlic-fresh & Lettuce & Pepper-thin & Red cabbage & Tomato \\
\hline
\end{tabular}

Table A7. Fruits

\begin{tabular}{llllll}
\hline Apple-Amasya & Banana & Grape-no seed & Kiwi & Nectarine & Pomegranate \\
\hline Apple-Golden & Blackberry & Grape-no seed to dry & Lemon & Orange-Other & Quince \\
\hline Apple-Grannysmith & Cherry & Grape-wine & Loquat & Orange-Washington & Raspberry \\
\hline Apple-other & Cherry & Grape-with seed & Mandarin-Satsuma & Peach & Strawberry \\
\hline Apple-Starking & Fig & Grape-with seed to dry & Melon & Pear & Tangerine-other \\
\hline Apricot & Grapefruit & Japanese Persimmon & Mulberry & Plum & Watermelon \\
\hline
\end{tabular}


Table A8. Feed crops and forages

\begin{tabular}{llll}
\hline Barley-CowFeed & Corn-Silage & Common vetch-forage & Trifolium-forage \\
\hline Beans-CowFeed & Soy-CowFeed & Lathyrus-forage & Triticale-forage \\
\hline Common vetch-grain & Soy-feed eggchicken & Oat-forage & Vetch-forage \\
\hline Corn-CowFeed & Soy-feed meatchicken & Rye-forage & Wheat-forage \\
\hline Corn-feed eggchicken & Alfalfa-forage & Sainfoin-forage & \\
\hline Corn-feed meatchicken & Barley-forage & Sorghum-forage & \\
\hline
\end{tabular}

\section{Copyrights}

Copyright for this article is retained by the author(s), with first publication rights granted to the journal.

This is an open-access article distributed under the terms and conditions of the Creative Commons Attribution license (http://creativecommons.org/licenses/by/3.0/). 